\title{
Paideusis
}

\section{"Teaching Defiance: Stories and Strategies for Activist Educators, a Book Written in Wartime" (Michael Newman)}

\section{Sara Catherine Carpenter}

Volume 16, Number 3, 2007

URI: https://id.erudit.org/iderudit/1072491ar

DOI: https://doi.org/10.7202/1072491ar

See table of contents

Publisher(s)

Canadian Philosophy of Education Society

ISSN

0838-4517 (print)

1916-0348 (digital)

Explore this journal

Cite this review

Carpenter, S. (2007). Review of ["Teaching Defiance: Stories and Strategies for Activist Educators, a Book Written in Wartime" (Michael Newman)]. Paideusis, 16(3), 83-86. https://doi.org/10.7202/1072491ar 
Review of

\title{
Teaching Defiance: Stories and Strategies for Activist Educators, a Book Written in Wartime
}

by Michael Newman, San Francisco: Jossey-Bass, 2006

\author{
SARA CARPENTER \\ OISE/University of Toronto, Canada
}

In my exploration of the variety of texts on critical/radical/activist education, I have found that many volumes seem to fall into one of two categories. Many are dense, rigorous theoretical expositions that leave the reader feeling inspired and excited for the intellectual and moral struggle of liberatory education. However, few of these texts prepare us for the on-the-ground pedagogical challenges we encounter when we are faced with a room full of learners. The other category does the opposite. These are often collections of activities, role-plays, facilitation methods, and reflection exercises. Sometimes these are very helpful, but they often feel as if they lack a critical, rigorous edge. Michael Newman's new text Teaching Defiance moves beyond this stalemate by offering a discussion that is both theoretically complex and rich with a multitude of suggestions from someone who is obviously a very seasoned educator.

Teaching Defiance is billed as a text for activist educators. The discussion, examples, and arenas of educational thought here are tightly situated within formal and non-formal adult education, particularly unions and community education. There is assistance here for educators working in more traditional environments, but it will take a little translation. The text is organized in five parts spanning discussions of the activist project of adult education, rational and irrational approaches to learning, and the importance of "constructing" moralities and making choices.

Drawing from Marx, Sartre, Camus, and the critical theorists, Newman begins the text with his own vision of adult education. For Newman, the contemporary project of activist educators is helping people to "take control of their moment."

\footnotetext{
Our job is to help people become truly conscious, understand the different worlds we live in, and develop a morality in the face of the evident amorality of our universe. It is to teach people how to make up their own minds, and how to take control of their moment. It is to teach choice... our job is to teach defiance. (Newman, 2006 p. 10).
}

He talks about the need to take sides, to make choices, to cultivate critical thinking as a learned skill, and the need for activist adult educators to commit to this moral project, which begins with inspiring rebelliousness in adult learners. For Newman, rebelliousness is a state of defying authority and convention; it can be ongoing or isolated, single incidents. He sites examples of a variety of rebellious activities from the conduct of Australian soldiers during the first World War to Rosa Parks to Gandhi to the student strikes in France in 1968. These examples demonstrate the range of rebellious activity that is possible. Throughout this discussion we are continually reminded of the critical importance of

(C) Copyright 2007. The author, Sara Carpenter, assigns to Paideusis the right of first publication and educational and non-profit institutions a non-exclusive license to use this document for personal use and in courses of instruction provided that the article is used in full and this copyright statement is reproduced. Any other usage is probibited without the express permission of the author. 
rebelliousness in social transformation. Newman then moves on to discussing how adult educators can inspire rebelliousness in learners. He reflects on his use of narrative, anger, and metaphors by providing stories and examples from his own practice.

In Part Two, Newman introduces the concept of defiance as different from rebelliousness. Rebelliousness can be disorganized, spontaneous, unaware. Defiance is more thoughtful. To Newman, defiance is a state beyond rebelliousness that involves choice, morality, and consciousness. Newman situates his discussion of choice within Turner (1980) and draws from existentialist, postmodern, and critical traditions. For Newman, Turner's anti-apartheid text is a claim to the possibility and responsibility of choice. These choices

may be fatuous and insignificant, they may be profoundly moral or they may be the question of being itself. But making choices means continually assessing, restating or reworking our relationship with the world around us. (Newman, 2006, p. 64).

Thus to be defiant is to make the choice; it is an expression of will. Newman's understanding of consciousness will be something very familiar to critical adult educators. His expansive discussion of the concept includes meditation, contemplative, and critical forms consciousness as well as reflections on Sartre's discussion of consciousness and the other. Ultimately, Newman advocates for a combination of these understandings coupled with a consciousness that is explicitly action-bound and choice-making and thus involves a commitment to values. For Newman, when we are critically conscious and making choices, our rebelliousness can become defiance.

Newman argues that teaching defiance can be done through both rational and irrational methods. In Part Three Newman details his understanding of choice and decision-making as learned skills and proposes a model for collective decision-making. This model includes learning how to discuss in a dialogical manner (following Allman, 2001). It also includes a discussion of negotiating difference in which Newman draws on Weber, Arendt, and Foucault to talk about difference and power. Of particular interest here is the abundance of strategies offered, including an interesting discussion of the use of theater concepts to generate more productive role-play. Newman thoroughly grounds this discussion in his extensive experience as an adult educator. He walks the reader through each tactic and reflects on his own experiences using these strategies with groups.

In Part Four, Newman wades into the murky water of learning through irrational methods. Rational discourse, and its resulting techniques, are perhaps old hand to adult educators. Mastering the facilitation of learning from irrational discourse is one of the most difficult and important skills of activist educators, since irrationality speaks to the heart of issues of oppression and social justice. For Newman, irrational discourse is centered on the uneven terrain of "insight," an illusive concept, which Newman attempts to nail down through a variety of examples, most successfully through Catch-22. Insight is "a realization, a sudden knowing, an instantaneous understanding...insight is as much an emotion as an act of intellect... an elation flowing into satisfaction, or a horror flowing into resignation or resistance" (Newman, 2006, p. 176). Insight is something that cannot necessarily be taught as it must come from inside of us. Thus Newman provides a chapter on a variety of methods for facilitating insight including using literature (with a nice discussion of Vonnegut, Shakespeare, and Don Marquis), metaphors, role play, and forum theater. Throughout this discussion of "methods" is a very important thread of the epistemology behind the facilitation of insight. For Newman, the process of coming to insight is a process of knowing things in a previously unknown way through unknown methods. It is Freire's process of naming and renaming. Newman concludes this section by bringing insight (or the irrational) into a relationship with the rational, choice and action. Choices, as Newman repeatedly argued throughout the text, must be made and action must be taken. He takes the time to detail a variety of frameworks for action, social movements, control, and learning, and integrates his discussion of insight with the classic Highlander question: what do we do now? In his closing thoughts in Part Five Newman dives into the stickiest of issues associated with teaching defiance: morality. Here 
Newman follows his argument that activist educators and their students can learn to choose defiance with the proposal that these choices can be moral and that the best method for constructing this morality and making these choices is storytelling. In order to make these choices, however, we must confront issues of love, hate, anger, and violence.

The primary strength of this text is the method Newman uses to teach the reader what he knows about radical education. Every section, chapter, and sub-chapter of this book in anchored in narrative. Newman clearly understands how people learn, or at least people for whom English is a first language as he points out in a very interesting discussion on the structure of the English language. Every abstract thought is brought back to someone's experience, to someone's story. Every big idea is grounded in practice and reflection. As much as I love the stories, I have to admit that at times it felt as though we were wondering off topic. A few of the stories become distractions from the question at hand and the eventual return to the point of the story feels disconnected. Another reviewer (Delgado, 2007) identified this disconnection as resulting from the second-hand nature of many of the stories. It is perhaps also a problem of the method overtaking the exposition. Storytelling is an enormously powerful learning tool; one that Newman tirelessly advocates throughout the book. But storytelling is also messy and that is simply its limitation.

Newman's defense of defiance raises a set of important questions concerning the relationship between this text and the larger body of what might be termed critical or radical adult education. There is a tension within this body of work between opposing purposes of critical adult education. On the one hand there is the long tradition of Marx, Gramsci, and Freire, each of whom saw education as central to the upheaval of capitalism. Within this tradition, concepts like critical consciousness, critical praxis, and revolution are central and emancipation is understood as the abolition of the labor-capital relation. Then there are the newer traditions, which stop short of calling for a socialist alternative and instead see the development of consciousness and agency as ends in themselves or simply call for the development of civil society (Holst, 2007). These tensions have not been bad or unnecessary as critical educators have confronted the question of class primacy and opened up radical education to questions of culture and recognition, not just redistribution.

Teacbing Defiance rides into the middle of this debate. Yes, classic Freire and Marx concepts are part of Newman's vision, but they are not the only game in town and Newman stops short of discussing the outcomes of defiance. There is also a heavy emphasis on existentialism and Mezirow influences Newman as well, particularly in his emphasis on the role of rational discourse in learning. Indeed, his thoughts on rationalism and his strategies for working with rational discourse in the classroom comprise the largest section of the text. It is also the addition of irrationality that makes this work unique. It is not that learning from irrationality is new, but we are reminded of its importance as Newman thoughtfully engages with questions of anger, violence, hate, and love. What is missing from Newman, and is central to critical education theorists including Gramsci, Freire, and Horton, is the emphasis on historicity and material conditions. There is little discussion of the learner's past or experience in Newman's treatment of pedagogy and epistemology. Many of his examples seem to focus more on grounding philosophical insights or simple drawing inspiration from past events. There is no sense that, as Horton has said, "everything comes out of the past and goes beyond" (Horton \& Freire, 1990 p. 7). What is good about this approach, however, is that Newman seems to be theorizing about the education of diverse populations and diverse perspectives while somehow avoiding the worst versions of anything goes relativism and pluralism. Everyone is a potential agent of social transformation and thus the political implications are heartening for activist educators from a variety of arenas of learning: schools, universities, and communities. 


\section{References}

Allman, P. (2001). Critical education against global capitalism: Karl Marx and revolutionary critical education. London: Bergin \& Garvey.

Delgado, A. (2007). Teaching defiance: Stories and strategies for activist educators [Electronic Version], Adult Education Quarterly, 57, 178-182. Retrieved May 26, 2007 from aeq.sagepub.com.

Holst, J. D. (2007). The politics and economics of globalization and social change in radical adult education: A critical review of recent literature [Electronic Version]. Journal for Critical Education Policy Studies, 5. Retrieved May 11, 2007 from www.jceps.com.

Horton, M. \& Freire, P. (1990). We make the road by walking: Conversations on education and social change. Brenda Bell, John Gaventa, and John Peters (Eds.). Philadelphia, PA, USA: Temple University Press.

Turner, R. (1980). The eye of the needle: Towards participatory democracy in South Africa (2nd ed). Johannesburg, South Africa: Ravan. 